\title{
Geometry and kinematics of the Fuegian thrust-fold belt, southernmost Andes
}

\author{
Pablo J. Torres Carbonell ${ }^{1}$, Leonardo Rodríguez Arias ${ }^{2}$, and Mario R. Atencio ${ }^{2}$ \\ ${ }^{1}$ Centro Austral de Investigaciones Científicas (CADIC-CONICET), Ushuaia, Tierra del \\ Fuego, Argentina, ${ }^{2}$ YPF S.A., Ciudad Autónoma de Buenos Aires, Argentina.
}

Corresponding author: Pablo J. Torres Carbonell (torrescarbonell@ cadic-conicet.gob.ar)

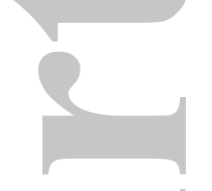

\section{Key Points:}

- Different participation of structural packages in deformation produce structural style variations along the thrust-fold belt

- Involvement of structural packages depends on suitable detachments, controlled by pore pressure related to sedimentation and strain-rate

- Basement thrust-sheets in the foreland thrust-fold belt are reported for the first time from subsurface data

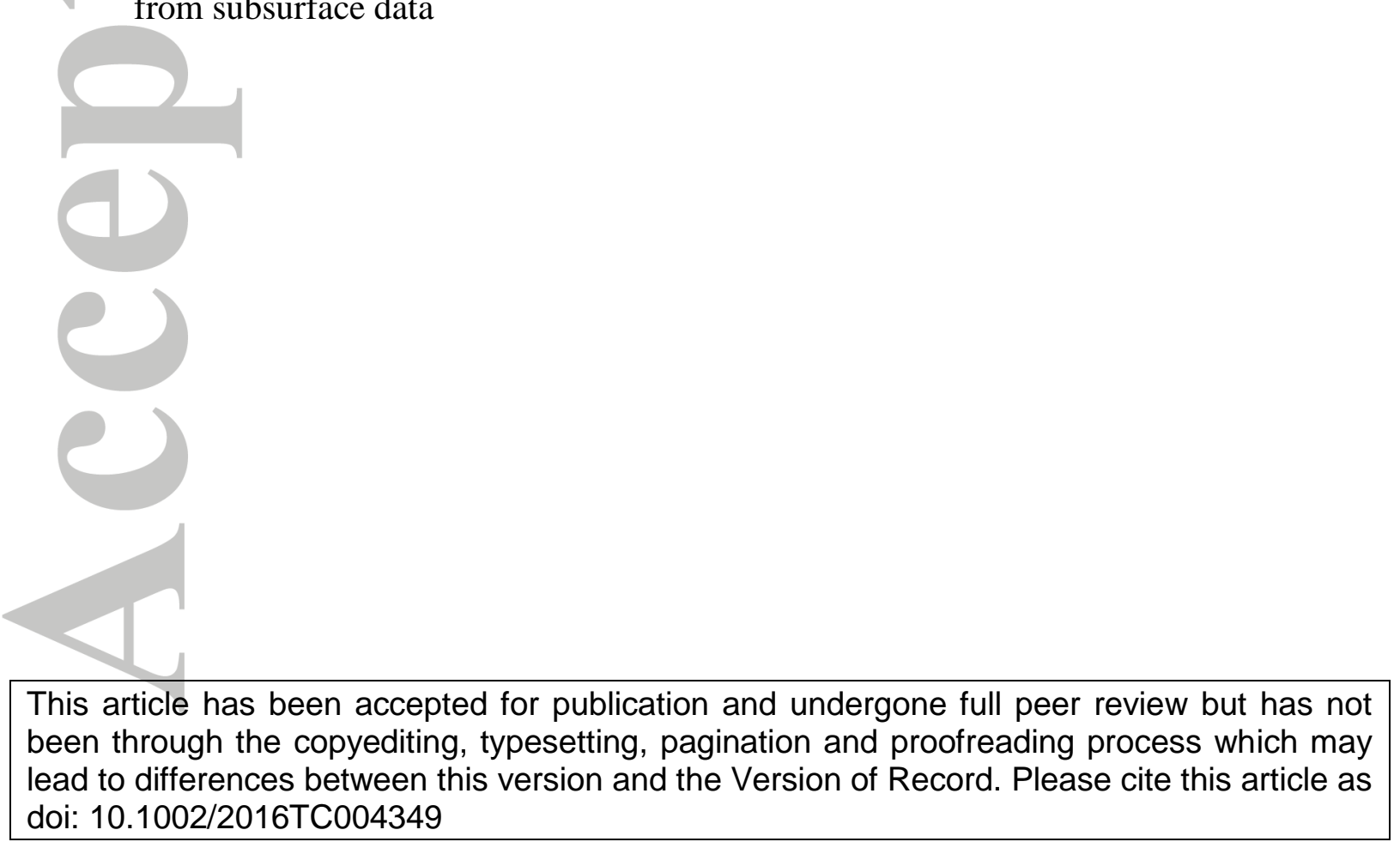

(c) 2016 American Geophysical Union. All rights reserved. 


\section{Abstract}

Published balanced structural interpretations of the Fuegian thrust-fold belt (southernmost Andes) fail to address aspects such as basement shortening in the thrust-fold belt, or its structural connection with the central belt of the orogen. We tackle this deficiency by constructing four serial balanced cross-sections based on surface geologic information, 2D reflection seismic lines, and well logs, which depict the first-order structural geometry and kinematics from the thrust front to the internal thrust-fold belt. The interpretation reveals three main tectonostratigraphic packages separated by major detachments: basement (Paleozoic-Upper Jurassic), Cretaceous, and Paleogene, all variably involved in thrusting along strike. Minimum shortening in the Paleogene cover ranges between $16 \%$ and $43 \%$, and significant style changes are observed across and along the thrust wedge. We show that basement thrust-sheets have a major role in the construction of the thrust-fold belt; some of them were emplaced below the thrust front during late Oligocene or early Miocene times. The kinematic evolution of the thrust-fold belt indicates that the active detachments depended on the existence of high pore pressure to propagate forward. Our model shows that this pore pressure buildup was controlled by overburden, mean rock impermeability, and strain-rate; the variable interaction among these factors controlled the propagation and style of the thrustwedge. 


\section{Introduction}

The role of basement deformation in thrust-fold belts has been widely discussed since interest in these regions of crustal shortening started. The involvement of basement in foreland shortening is usually important in areas were thrust-fold belt growth was preceded by extensional tectonics. A good review of the manner in which deep-rooted deformation dominates these tectonic settings has been recently given by Lacombe and Bellahsen [2016]. However, even if basement is not neglected in deformation, it is often difficult to distinguish the mode in which portions of crust participate in the construction of the thrust-fold belt. For example, in the thick-skinned thrust-fold belt of the Central Andes there has been much debate concerning models of inversion of normal faults [Mescua and Giambiagi, 2012] vs. generation of new basement thrust-sheets [Dimieri and Turienzo, 2012]. Both modes of deformation have been proposed for better known orogenic belts, and it is clear that even when they are not reactivated, pre-existing faults in rifted basement constitute mechanical discontinuities that favor buttressing and localization of thrust ramps [Lacombe and Bellahsen, 2016]. Indeed, buttressing against preexisting basement promontories is often responsible for lateral structural style changes and development of orogenic curves [Marshak, 2004].

The construction of good balanced cross-sections is very useful to address and discuss different structural models in thrust-fold belts formed during the inversion of prior extensional basins. This kind of cross-sections give the necessary structural framework on which subsequent studies can add stratigraphic data and time constraints, for example, which permit to enhance geometric, kinematic, and mechanical models of thrust-fold belts. This task gets major significance when the importance of these belts for exploration of natural resources is considered. 
The Fuegian thrust-fold belt constitutes a good case study where shortening involved the inversion of a prior basin formed on stretched crust. It has attracted increasing interest in recent years, since it has important potential for hydrocarbon exploration, bordering an area of active production in the Austral-Magallanes basin of southern Chile and Argentina. Basement is known to be affected by deformation, especially from outcrops in the central belt of the Fuegian Andes [Klepeis et al., 2010]; and prior normal faults have been shown to exert a buttressing effect in the foreland subsurface [Torres Carbonell et al., 2013a]. An important orogenic curve is formed along the thrust-fold belt, with structural style changes both across and along its strike, as shown in balanced cross-sections [Alvarez-Marrón et al., 1993; Torres Carbonell et al., 2011; 2013a]. However, most of the published balanced cross-sections describe thin-skinned structures in the foreland portion of this thrust-fold belt based on limited outcrop and some seismic data. None of them fully address the geometry and kinematics of the Fuegian thrust-fold belt. For example, involvement of the basement on the foreland thrust-fold belt shortening, or the structural connection with the central belt of the orogen remains obscure in these studies. In the interpretations from the eastern Fuegian thrust-fold belt [e.g. Torres Carbonell and Dimieri, 2013], this lack of structural descriptions is caused by the need of constructing a cross-section along the Atlantic coast of Tierra del Fuego, whose strike is highly oblique to the structures; and by the presence of a late, major strike-slip fault interrupting the cross-section (Figure 1a). On the other hand, in cross-sections from the central and western thrust-fold belt, the structural interpretations are either of poor detail due to their regional scale [e.g. Rojas and Mpodozis, 2006], or limited to the thrust front [e.g. Torres Carbonell et al., 2013a], or to a selected thrust system within the belt [Alvarez-Marrón et al., 1993] (Figure 1b). The few studies that extend the description to more internal parts of the thrust-fold belt end up with contrasting models regarding the geometry and kinematics of deformation. For example, the uplift of basement rocks in the 
hinterland are either interpreted as related to out-of-sequence thrusting [Klepeis et al., 2010], or as part of a duplex thrust sequence kinematically related to the development of the foreland thrust-fold belt [Torres Carbonell and Dimieri, 2013].

In this work we fully address the geometry and kinematics of the Fuegian thrust-fold belt by selecting a region with sufficient seismic, well $\log$ and surface geological data, enabling the construction of a complete cross-section spanning the entire thrust fold-belt. Using the integrated dataset we constructed serial balanced cross-sections that depict a viable and restorable geometry for a previously overlooked part of the thrust-fold belt. By doing so, we propose a first-order constraint on the style and amount of shortening involved in the exploratory frontier of the Austral-Magallanes basin; we show that basement thrust-sheets play a major role in the construction of the thrust-fold belt; and we put forward an interpretation of the kinematic evolution of the thrust-fold belt, arguing that pore pressure buildup induced by overburden, mean rock impermeability, and strain-rate is an important controlling factor on the propagation and style of the thrust-wedge.

\section{Geologic setting}

The Fuegian Andes (Figure 1a) constitute the southernmost segment of the Andean Cordillera; they are distinct, however, since Andean-type convergence was not the main factor leading to orogenesis. On the contrary, the Fuegian Andes formed due to arc-continent collision, starting during the beginning of the Late Cretaceous and continuing until the early Neogene [Dalziel, 1986; Tanner and Macdonald, 1982; Cunningham, 1995; Kraemer, 2003; Klepeis et al., 2010; Torres Carbonell and Dimieri, 2013]. This distinctive feature owes to the fact that prior to orogenesis, the portion of SW South America now occupied by the Fuegian Andes was involved in Late Jurassic-Early Cretaceous continental stretching and formation of the Rocas Verdes back-arc basin. The SW border of this basin was formed by a 
volcanic arc, rooted in a strip of crust detached from the South American continent during extension [Dalziel, 1986]. The deepest part of this NW-SE trending basin was partially floored by oceanic crust [Calderón et al., 2007]. Therefore the initial stratigraphy of the region comprises (Figures 1a and 2): 1) a stretched Paleozoic basement, unconformably covered by 2) Upper Jurassic synrift volcanic, pyroclastic and sedimentary rocks (Lemaire Tobífera- Formation); 3) Uper Jurassic-Lower Cretaceous oceanic floor volcanics; and 4) a Lower Cretaceous clastic wedge filling the back-arc basin, grading from arc-derived turbidites and shales at the deep through, to marginal marine sandstones at the stable foreland (Yahgan, Beauvoir, Hito XIX, Springhill Formations, Lower Inoceramus, Margas Verdes) [Fildani and Hessler, 2005; Calderón et al., 2007; Olivero and Malumián, 2008, and references therein]. Some of these units define the major operational hydrocarbon system in the study area (Figure 2).

The most probable cause for closure of the Rocas Verdes basin was the Late Cretaceous increase of spreading rate at the mid-Atlantic ridge, which caused a fast drift of South America toward the Pacific [Dalziel et al., 2013]. Basin closure proceeded through collision between the volcanic arc and the stable cratonic South American margin [Klepeis et al., 2010]. Collision probably involved some degree of counterclockwise rotation of the magmatic arc [Torres Carbonell et al., 2014; Poblete et al., 2016]. The kinematics of basin closure included obduction of the SW portion of the basin floor, now partly exposed as an ophiolitic belt along the southernmost Andes (Figure 1a); and continental underthrusting of the NE margin of the basin [Klepeis et al., 2010]. This mechanism of closure caused north and NE directed ductile deformation (mostly simple shear) of the basement and overlying volcanic-sedimentary rocks [Bruhn, 1979; Tanner and Macdonald, 1982], forming an initial orogenic wedge that bulldozed the coeval foreland basin ahead of it [Torres Carbonell and Dimieri, 2013]. Simple shear deformation was intense at the root of the orogen, where 
associated high-grade metamorphism occurred [Nelson et al., 1980; Kohn et al., 1993], whilst it provoked brittle thrust-related deformation in the shallow, external portions of the orogen.

Consequently with the progressive evolution of orogenesis, the ductilely deformed metamorphic rocks where uplifted and exhumed by thrust emplacement [Klepeis et al., 2010]. Thrust faulting affected the upper crust of the underthrusting South America plate from the Late Cretaceous to the Neogene, forming a major crustal duplex [Torres Carbonell and Dimieri, 2013]. The sequential emplacement of thrust-sheets in this major duplex allowed the progressive uplift of the basement in the central belt, starting with an early cooling stage between 90-70 Ma, followed by relatively slow cooling between 60 and $40 \mathrm{Ma}$ with a peak cooling at about $50 \mathrm{Ma}$ [Kohn et al., 1995]. Low temperature thermochronology from the Lemaire Formation and a pluton intruding the Yahgan Formation, indicate an episode of rapid cooling between $\sim 48$ and $\sim 36 \mathrm{Ma}$ [Gombosi et al., 2009]. Detritus eroded from the Lemaire Formation evidence pulses of exhumation of the central belt during the Campanian, Eocene, and Oligocene, indicating orogenic unroofing during the emplacement of the crustal duplex [Olivero et al., 2003; Malumián and Olivero, 2006; Barbeau et al., 2009]. This duplex model explains the kinematic evolution of the orogen and the transference of orogenic shortening to the foreland, as recorded in the thrust-fold belt [Torres Carbonell and Dimieri, 2013].

Figure $1 \mathrm{~b}$ shows the location of a number of published structural cross-sections of the thrust-fold belt, or portions of it. A common observation in the majority of these sections is the thin-skinned style of the thrust-fold belt, with two main detachments: at the base of the Cretaceous succession, and at the base of the Paleogene succession. Most of the crosssections are located in the frontal part of the thrust-fold belt, and show shortening magnitudes which can only be compared from a regional perspective, since they are obtained using different methods and scales of section construction. An attempt of comparison is shown in 
Table 1, which shows magnitudes ranging from $\sim 30$ to $60 \mathrm{~km}$ of shortening in the sedimentary cover, and from $\sim 15$ to $65 \mathrm{~km}$ of shortening in regional cross-sections.

Aside from shortening magnitudes, existing cross-sections differ in how they interpret the connection between the internal orogen and the thrust-fold belt domain. Some previous studies [Kley et al., 1999; Klepeis et al., 2010] consider a basement domain that was uplifted "out-of-sequence" with respect to the foreland thrust-fold belt. On the other hand, previous work proposes an orogenic wedge that evolved through the emplacement of a major crustal duplex that progressively transferred shortening to shallow structural levels in the foreland, creating the thrust-fold belt [Torres Carbonell and Dimieri, 2013]. This latter model implies the progressive forward emplacement of basement thrust-sheets, which must be present below the external thrust-fold belt. Hard evidence supporting the existence of these deep thrust-sheets is reported for the first time in this contribution.

In contrast to the eastern portion of the Fuegian thrust-fold belt, where reasonably good stratigraphic resolution allows constraining several stages of thrust advance [Torres Carbonell et al., 2011], the stratigraphy in our study area is less known (Figure 2). The extensive outcrop of older rocks cropping out in the southern portion of the area (Figure 1b), however, allow to distinguish between two different generations of structures. The first generation (D1 structures -D' in Torres Carbonell et al., 2013b-) formed at intermediate structural levels in the crust and characterizes the initial deformation of the internal thrustfold belt. The second generation (D2 -D'" in Torres Carbonell et al., 2013b-) formed during uplift of the internal thrust-fold belt and further thrust propagation at shallow depths (less than 5-6 km). Age constraints for both generations come from the regional unconformity that separates the younger rocks with disjunctive foliations (Policarpo Formation, MaastrichtianDanian) from the Paleocene Tres Amigos Formation (Cerro Apen Beds) (Figure 2). This unconformity is slightly angular at some sites [Torres Carbonell et al., 2011], and coincides 
with an increased input of coarse detritus to the foreland basin, derived from erosion of the Fuegian Andes core [Barbeau et al., 2009]; all of which suggest orogenic contraction and uplift between the Late Cretaceous and the Paleocene correlated with the D1 structures [Torres Carbonell et al., 2013b]. Subsequent deformation during the D2 generation acted from the Eocene to the late Oligocene or early Miocene, as suggested by syntectonic unconformities in the eastern thrust-fold belt [Torres Carbonell et al., 2011]. The youngest age of deformation in the thrust front is constrained by progressive angular unconformities [Ghiglione et al., 2010; Torres Carbonell et al., 2013a].

\section{Methodology}

We use a dataset of $2 \mathrm{D}$ reflection seismic lines that cover $6,300 \mathrm{~km}^{2}$ of the central part of Tierra del Fuego (Figure 1b). The lines were interpreted using the Move software (2015-2016 academic licenses from Midland Valley). In addition, we processed selected lines using the SimilTecVA attribute, which allows a best definition of contrasting lithologies and major fracture zones using the amplitude of the seismic traces. This technique was developed by Bulhões and Nogueira de Amorim [2005]; we performed it including the normalization of seismic amplitudes, the calculation of the absolute value of the traces, and a phase rotation of $90^{\circ}$. In this manner, we obtained a seismic attribute comparable to the TecVA attribute calculated for sliding windows of a few milliseconds [Atencio et al., 2014]. The SimilTecVa workflow improves the continuity of the reflectors, which are highlighted in seismic sections. The visual impression obtained is more "geological", and aids in the interpretation of faults in subsurface. Finally, some of the seismic sections were depth-scaled using an interval velocity model, obtained from the extrapolation of low-frequency well velocities $(0-15 \mathrm{~Hz})$ from wells near the selected lines. 
The stratigraphy was taken from well logs (located in Figure 1b) and previous cartography [SERNAGEOMIN, 2003; Olivero and Malumián, 2008; Martinioni et al., 2013], and follows the nomenclature used in the Argentine subsurface (Figure 2). Finally, we added structural data from our surface mapping and from previous work [Alvarez-Marrón et al., 1993; Zanella et al., 2014], which is scattered and limited to river cuts and hills above the treeline.

The balanced cross-sections (shown in Figures 3 and 4) are oriented perpendicular to the structural trends, and were constructed following the fault-bend and fault-propagation fold models of Suppe [1983] and Suppe and Medwedeff [1990]. They were afterwards redrawn in Move software in order to honour the fold geometries observed in seismic sections. The tools of this software allowed us to balance the sections through conservation of bed length and area, with area differences between the deformed and restored cross-sections below 5\%. In addition to the assumptions inherent to section balancing using the cited models, we emphasize the following: 1) we did not apply backstripping or depth corrections associated to restoring the flexural subsidence in the foreland basin successions; 2) we did not consider the unavoidable ductile deformation below depths of $\sim 10 \mathrm{~km}$, or the layer-parallel shortening and pressure-solution foliation whose development is known for the Cretaceous rocks of the internal thrust-fold belt [Torres Carbonell et al., 2013b]. As will be discussed in section 5, however, this layer-parallel shortening pertains to a deformation phase (D1) that is older than the deformation depicted in the cross-sections (D2); and 3) the folds depicted in the internal thrust-fold belt are first-order folds, which we interpret as associated with major thrust faults; the higher-order folds observed in that region are not depicted. This latter assumption allows only for a range of plausible shortening magnitudes to be estimated for the internal thrust-fold belt. The same can be said about the style and shortening magnitudes of the basement structures; in the cross-sections we only show the amount of basement that was 
necessarily affected to generate the shortening that formed the structures in the thrust-fold belt [cf. Torres Carbonell and Dimieri, 2013].

These simplifications allow us to test the viability of first-order crustal structures, such as major thrust-sheets carrying rock masses that are internally deformed; to portray time-slice depictions of the kinematic evolution of the thrust wedge; and finally to obtain a minimum amount of orogenic shortening, as a starting point from which the addition of higher-order strain could be addressed in future work [cf. Ramsay et al., 1988]. To the best of our knowledge, the geometries that we interpret are those that could most reasonably explain the structures imaged by the available seismic dataset. In places without seismic coverage, or where data quality is too low, we interpret geometries that could be integrated in a viable and restorable manner with the best-constrained structures. In other words, until denser, higher quality information is made available, any balanced section interpretation would bear similar uncertainties.

\section{Geometric analysis}

4.1. Detachments and major tectonostratigraphic packages

Three tectonostratigraphic packages are distinguished in the balanced cross-sections from Figures 3 and 4: 1) A structural basement, which includes Paleozoic rocks and the Jurassic Lemaire Formation (see Figure 2), forming a duplex between basal and roof detachments, the latter (Detachment K) at the base of the Cretaceous package. 2) A Cretaceous succession affected by thrusts branching from Detachment $\mathrm{K}$, which either cut through the overlying rocks (e.g. section A-A' and B-B') or form duplexes within the basal Cretaceous package (e.g. section C-C'), or duplexes that connect to a roof detachment at the base of the Paleogene succession (Detachment P) (e.g. sections C-C' and D-D') [see also Alvarez-Marrón et al., 1993; Zanella et al., 2014]. 3) A Paleogene package imbricated by 
thrusts that branch from Detachment $\mathrm{K}$ cutting through the Cretaceous and Paleogene packages, or branch from Detachment P; both types with associated fault-bend and faultpropagation folds. Some of the ramps have upper flat segments in several Paleogene levels, especially in the Eocene rocks, and a few cause passive delamination along backthrusts forming local triangle zones (section A-A').

The existence of the first tectonostratigraphic package (basement) is a geometric requirement to balance the shortening accommodated within the two younger packages, which must be generated from deeper levels in the crust [Torres Carbonell and Dimieri, 2013]. As such, the basement thrust-sheet geometries in Figures 3 and 4, though balanced, are arbitrary (see previous section). The uplift caused in the cover above the stacked basement thrust-sheets explains the surface exposure of deep structural levels of the Cretaceous package in the internal thrust-fold belt (see below), and is consistent with at least one antiformal stack mapped south of the internal thrust-fold belt [Klepeis et al., 2010]. In addition to these theoretical impositions, however, seismic reflection profiles in the area crossed by section A-A' reveal the existence of such basement thrusting, with a well-defined upper detachment both at the base of the Cretaceous (Detachment K) and at the base of the Paleogene (Detachment P) (Figure 5). The detachment below the basement, on the other hand, is beyond seismic resolution.

Detachment $\mathrm{K}$ is not only established from the seismic interpretation, but also crops out as Lower Cretaceous shales at the base of the Vicuña imbricate fan (Figure 1b). These shales where probably subjected to overpressure due to hydrocarbon generation during the thrust-fold belt evolution, which in turn enhanced their suitability as detachment horizons [Zanella et al., 2014]. Detachment P, on the other hand, does not crop out in the study area, although it is clearly seen in the seismic lines, especially in the frontal thrust-fold belt (Figure 5a-d) [Torres Carbonell et al., 2013a]. Nevertheless, this detachment level is exposed at the 
base of a major thrust-sheet in the eastern Fuegian thrust-fold belt, along the Atlantic coast of Tierra del Fuego [Torres Carbonell et al., 2011].

4.2. Internal and external thrust-fold belt

The internal and external portions of the thrust-fold belt are clearly separated by the Apen-Malyinera thrust system (AMTS), a fault system that is recognized throughout the Argentine part of the Fuegian Andes from the Atlantic coast to the international boundary with Chile, and is correlated and continued toward the west with the Colo-Colo and Yartou thrusts (Figure 1). Between sections B-B' and C-C', however, the boundary between the external and internal thrust-fold belt shifts northwards to the Vicuña imbricate fan (Figure 1b) [Alvarez-Marrón et al., 1993; Zanella et al., 2014].

The AMTS and the Vicuña imbricate fan separate a large slate belt to the $\mathrm{S}$, from coarser clastic successions to the N, which include Paleogene to lower Neogene rocks (Figure 1b) [Torres Carbonell et al., 2013b; Zanella et al., 2014]. The AMTS has a morphological expression manifested by the alignment of elongate ranges formed by Upper Cretaceous slates and shales (Policarpo Formation), which in the higher summits expose Paleocene coarse sedimentary rocks (Tres Amigos Formation and Cerro Apen Beds) (Figure 6). Similarly, the Vicuña imbricate fan is distinguished as a series of long mountain ranges exposing Cretaceous rocks in the abrupt topographic break that marks the mountain front (Figure 6a).

The slate belt reveals D1 structures formed at intermediate levels in the crust, before uplift during the Paleogene [Torres Carbonell et al., 2013b]. The sequence of deformation involved a first episode of layer-parallel shortening with development of tectonic pressuresolution foliations, and probably very gentle folding (D1 structures), followed by emplacement of first-order thrust-sheets such as those depicted in cross-section C-C' (D2 
structures). Internally, the thrust-sheets reveal at least three orders of folds with NE vergence. The folded strata (interlayered well-cemented shales and very fine sandstones) form multilayers of moderate mean competence, but high competence contrast, which were deformed by a combination of flexure and flow folding, leading to alternating parallel (competent) and similar (incompetent) folds [cf. Ramsay, 1967; Torres Carbonell et al., 2013b]. The balanced cross-sections show the stacking of the Cretaceous package associated with the AMTS and Vicuña imbricate fan, which accumulate high amounts of shortening, allowing the slate belt to be exposed at the surface (Figures 3 and 4).

4.3. Lateral structural style variations along the thrust-fold belt

Previous work in the frontal part of the thrust-fold belt revealed significant lateral strain and structural style variations, probably owing to the increased buttressing against a basement promontory toward the eastern thrust-fold belt [Torres Carbonell et al., 2013a]. The present contribution adds further information about the nature of structural variations along the strike of the thrust-fold belt.

The most evident distinction is the style of basement thrusting, which dramatically changes between section A-A', in the western border of our study area, and sections B-B' to D-D' (Figures 3 and 4). In section A-A' the basement package extends forelandward forming a duplex below the complete thrust-fold belt. The two frontal horses transfer limited shortening to the upper Detachment $\mathrm{P}$, and minor backthrusting in the Paleogene package accommodates local deformation at the leading edge. An amount of shortening is transferred out (NE) of the section, and may be accommodated by a fold analogous to the one seen in the right border of Figure 5b. The southernmost basement sheets, on the other hand, transfer shortening to Detachment K. Most of that shortening is accommodated by the development of thrusts that cut with a ramp-flat style through the Cretaceous and Paleogene packages, and 
cause folding limited to the southern half of the cross-section. The front of this folded wedge is marked by minor backthrusts branching from a local detachment within the Paleogene package. Only very gentle folds occur in the Paleogene package in front of that position.

In contrast, in sections B-B' to D-D' the duplex in the basement package is constrained to the base of the internal thrust-fold belt. However, different styles are also detected between section B-B' and the other two sections. Sections C-C' and D-D' are very similar, both revealing a duplex in the Cretaceous package between Detachment $\mathrm{K}$ and Detachment $\mathrm{P}$, and the development of an imbricate fan of thrusts above Detachment $\mathrm{P}$, and related folds in the Paleogene package. A minor, possibly inverted normal fault is seen at the northern edge of section C-C', whereas the frontal structure of section D-D' is controlled by a step in the basement (see below). Cross-section B-B', however, shows poor development of a duplex in the Cretaceous package, and many of the thrusts branching from Detachment K cut through the Cretaceous and Paleogene packages. Only in the northern half of the section does Detachment $\mathrm{P}$ effectively bound a small duplex in the Cretaceous package, forming the base of the frontal imbricate fan. A normal fault, cutting the Cretaceous and basement packages, seems to control the location of the frontal ramp connecting Detachment K with Detachment P.

The surface expression of the thrust-fold belt is characterized by more or less continuous folds, recognized by linking range morphologies with subsurface fold axial traces. The folds can be traced along strike for tens of kilometers (at least $50 \mathrm{~km}$ in the longest anticline axial trace) (Figure 1b). Laterally, shortening is apparently distributed in the transfer zone between individual structures. No tear faults in the sedimentary cover are evident from our seismic dataset, but this could be a problem of sparse seismic coverage, since the separation of the available $2 \mathrm{D}$ sections is about the same, or larger, than the width of the transfer zones. 


\subsection{Buttressing against normal faults}

In general, all the seismic sections reveal the occurrence of normal faults below the thrust wedge, affecting the basement and occasionally the basal part of the Cretaceous package. These faults are inherited from the Late Jurassic-Early Cretaceous rifting that led to the opening of the Rocas Verdes basin. Most of them were not drawn in the balanced crosssections since they had no influence on the mechanics of the thrust-fold belt, being considered passive elements of the basement package.

There are several distinct normal faults, however, which are depicted in the crosssections since they affect not only the basement but also the Cretaceous and part of the Paleogene package. In Figure 7 we illustrate some of these faults, imaged by several seismic lines spaced along the faults' strike. The normal faults are oriented approximately WNWESE, parallel to the strike of the folds (Figure 7a). Most of the faults dip SW, but a few with NE dips are also present; the latter, however, only cut rocks as young as Cretaceous. One particular SW-dipping fault (Fault $\mathrm{x}$ in Figure 7) forms a step in the footwall of the thrustfold belt, which can be traced for a length of at least $18 \mathrm{~km}$. This step causes the branching of the frontal and youngest thrust from Detachment $\mathrm{P}$, associated with the Buenos Aires anticline (Figure 7c-d, see cross-section D-D', Figure 4b). A similar relationship between normal faults and thrust ramps was also depicted for the frontal thrust-fold belt $70 \mathrm{~km} \mathrm{NW}$ from this position [Torres Carbonell et al., 2013a], and observed in more internal parts of the thrust-fold belt, near our section A-A', by Alvarez-Marrón et al. [1993].

Faults $\mathrm{x}$ and $\mathrm{z}$ in Figure 7 cut beds as young as lower Paleogene, with tip lines reaching the strata below the top Lower Margosa marker. Growth strata between the top Lower Margosa and top Middle Margosa (Figure 7b-c), indeed, suggest that these faults were active during the middle and late Eocene (Figure 2). Conversely, the frontal Buenos Aires anticline is related to growth strata younger than the Middle Margosa marker (Figure 7c-d), 
indicating an Oligocene-Miocene age for the end of thrust-related folding [Ghiglione et al., 2010; Torres Carbonell et al., 2013a].

The interpretation of these faults deserves further discussion, since recent work in the area suggested that they were active during an inferred stage of Neogene rifting in the Magellan strait [Ghiglione et al., 2012]. We were unable to observe evidence of Neogene activity in these faults, since the only growth strata clearly associated with them are of Eocene age (Figure $7 \mathrm{~b}-\mathrm{c}$ ). We consider, on the contrary, that the majority of these faults where either new or reactivated Late Jurassic faults that accommodated local extension due to flexural loading in front of the thrust wedge. This kind of response of preexisting and new normal faults upon flexural loading in foreland basins, has been documented in many other similar geological settings [Bradley and Kidd, 1991; Agarwal et al., 2002; Londoño and Lorenzo, 2004; von Hartmann et al., 2016], including the South Malvinas basin which is laterally linked to the Austral-Magallanes basin [Platt and Philip, 1995; Bry et al., 2004]. It is also interesting to point out, regarding interpretations of inversion of normal faults published elsewhere [Betka et al., 2015], that only one possible inverted normal fault, with a displacement of a few hundred meters, was recognized within our dataset (section C-C'), suggesting no major influence of inversion tectonics during shortening in the Fuegian thrustfold belt. 


\subsection{Shortening}

A strong increase in the shortening percentage of the Paleogene package toward the east is revealed by the balanced cross-sections (16\% to 43\%). This is consistent with previous observations of a strain increase in the deformation front toward the apex of the Península Mitre recess (Figure 1a), accompanied by a complexity in the structural style, as mentioned before [Torres Carbonell et al., 2013a]. Only sections C-C' and D-D' completely cross the internal thrust-fold belt (Figure 4). Both reveal a uniform shortening during formation of this belt $(25-28 \%)$, which however must be considered with caution since the structures there are less accurately constrained than in the external thrust-fold belt. In addition, even if most of the penetrative deformation in the Cretaceous package occurred prior to thrusting (during D1), at least part of the higher-order folding within the thrust sheets, accompanied by some volume loss due to pressure-solution foliation, could occur during thrust emplacement [cf. Torres Carbonell et al., 2013b]. This suggests that the calculated shortening of the internal thrust-fold belt should be considered only a plausible lower boundary for the amount of deformation.

The available structural information used by Torres Carbonell et al. [2013a] suggested that the shortening changes along the thrust-fold belt (between 5 and $15 \mathrm{~km}$ ) were not significant at the regional scale, and thus in that work it is argued that the buttressing effect was the most important factor in conditioning structural style and strain changes at the thrust front. However, these conclusions were based on shortening estimates from cross-sections made using different methods (Table 1\%. Our new estimate, based on serial cross-sections constructed and restored following a single set of assumptions and coherent techniques, reveals that indeed regional shortening increases toward the east more than was previously assumed. This means that the complexity of the structural style in the eastern 
Fuegian thrust-fold belt could be the result of both buttressing (more important in the deformation front) and the increased regional shortening toward the east.

\section{Kinematic analysis}

5.1. Temporal evolution of the thrust-fold belt

Two main stages characterize the regional kinematics of the thrust-fold belt, which involve the initial growth of the thrust wedge (stage D1) and its subsequent propagation coupled with the evolution of the external thrust-fold belt (stage D2) [Torres Carbonell et al., 2013b]. The kinematic evolution of the balanced cross-sections shown in Figures 3 and 4 mostly pertains to stage D2 (Paleocene-early Miocene), during which the depicted thrust systems propagate forward into the foreland basin fill.

We interpret here that the AMTS (Apen Malvinera thrust system) has a major importance in carrying the internal portion of the orogenic wedge toward the foreland during early Paleogene time, probably at the beginning of stage D2. As seen in the balanced crosssections, a minimum shortening roughly between $25 \%$ and $28 \%$ is accommodated by thrusts branching from Detachment $\mathrm{K}$ in the internal thrust-fold belt (Figure 4). In sections C-C' and D-D', the AMTS is approximately the frontal boundary of this thrust system, and its footwall forms a partially exposed duplex of Cretaceous horses (Sierra Nevada antiform) that uplifts Paleogene rocks at its frontal (NE) flank. In sections A-A' and B-B', however, the footwall of the AMTS is formed by imbricate thrusts in Cretaceous rocks (Vicuña imbricate fan), which replace the AMTS as the exposed boundary of the internal thrust-fold belt [see also AlvarezMarrón et al., 1993; Zanella et al., 2014]. Displacement on the Vicuña imbricate fan brought Lower Cretaceous rocks to the surface. The AMTS and Vicuña imbricate fan were active at least until/ the late Eocene, since their footwall includes the Glauconítico B and Lower Margosa (Figure 2). 
The duplex formed in the footwall of the Vicuña imbricate fan (in sections A-A' and B-B') and of the AMTS (in C-C' and D-D') acts as an intermediate structure involved in the transfer of shortening from the basement duplex in the orogenic core to the structures formed above Detachment P. In this manner, the external thrust-fold belt evolved mainly by emplacement of thrusts and related anticlines, accommodating the shortening carried from deeper structural levels.

The position of the frontal structures, as mentioned before, is usually conditioned by the presence of fault-related steps, except in section A-A', where basement thrusting has propagated below the external thrust-fold belt. The age of basement thrusting in section A-A' is as young as Oligocene, which is the age of the sedimentary rocks affected by deformation in the thrust front (Figure 1a). In all the seismic sections that cross the frontal structures, the youngest deformation is also dated to late Oligocene or early Miocene times by progressive unconformities developed in the Upper Margosa unit (Figure 7c-d). Therefore, the basement duplex that exports deformation toward the foreland has been active until these times. This is consistent with all the published information on cooling and exhumation of basement rocks in the central belt of the Fuegian Andes, which indicate their progressive uplift from the Turonian to the late Eocene [Nelson, 1982; Kohn et al., 1995; Gombosi et al., 2009; Barbeau et al., 2009]. Rocks of the Lemaire Formation thrust over late Eocene strata in an intermontane basin in the central belt [Olivero and Malumián, 2008] also suggest that basement thrusting may have continued after the Eocene. 
5.2. Controlling factors on the propagation and style of the thrust-wedge

As mentioned before, the frontal structures of the internal thrust-fold belt (AMTS and Vicuña imbricate fan) acted as the leading edge of deformation until the Eocene, accommodating important amounts of shortening above Detachment K. At some point after the early or middle Eocene, the sole thrust propagated forward and also upward to form Detachment P at the base of the Paleogene package (Figures 3 and 4). We analyze here the reasons that we consider most plausible for the unblocking of a long-lived thrust front, which allowed growth of the external thrust-fold belt.

Until the Eocene, Detachment $\mathrm{K}$ was evidently weak enough to favor large displacement along a frontal ramp (AMTS or Vicuña frontal ramps), but it had a blocked termination line. The weakness of Detachment $\mathrm{K}$ was caused by abnormally high pore pressure owing to hydrocarbon generation in Lower Cretaceous shales near the detachment, as evidenced by bedding-parallel fibrous veins (beef veins) in these source rocks [Zanella et al., 2014]. An additional contribution to overpressure in these shales could come from porosity reduction due to inelastic strain and pressure-solution [cf. Walder and Nur, 1984], both because of overburden and tectonic compaction during the development of prior D1 structures. All these triggering factors for pore pressure buildup are increasingly important toward the hinterland of the thrust-wedge, because they depend on overburden (foreland basin sedimentation plus tectonic stacking) and strain (lower toward the foreland). Therefore they decrease toward the front of the thrust wedge, meaning that at some point the pore pressure is not high enough to make a suitable detachment [Cello and Nur, 1988].

Hence, to unblock the detachment front and force its propagation during the Eocene, both overburden and strain-rate had to increase, creating abnormal pore pressure ahead of the blockage (Figure 8). A rise in overburden during the early Paleogene is supported by the deposition of Eocene interlayered shale-sand deposits, including the Lower Margosa, 
Glauconítico B and Midle Margosa, at the least, before renewed propagation of the thrust front (section 5.1). High fluid pressure owing to overburden is indeed common in the AustralMagallanes basin, as evidenced by numerous clastic dikes exposed in different units of the Paleogene package.

According to Cello and Nur [1988], the pore pressure buildup accompanying overburden is enhanced by strain-induced porosity reduction, mainly caused by tectonic compaction. If porosity reduces sufficiently fast to generate overpressure in a distance large enough (i.e. the length of the future thrust-sheet), then the detachment propagates and a new thrust-sheet is emplaced (Figure 8). This process needs a low effective rock permeability in the stratigraphic section, in order to function [Cello and Nur, 1988; Mourgues and Cobbold, 2006]. The shaly nature of the Cretaceous and Paleogene successions in the Fuegian thrustfold belt (Figure 2) most likely favored this process. Evidence for a strain-rate increase can be indirectly obtained from the chronology of exhumation in the central belt of the Fuegian Andes. Low-temperature termochronology data indicate that the hinterland of our study area experienced rapid uplift during the middle and late Eocene, with a peak in Cordillera Darwin around 50 Ma [Nelson, 1982; Kohn et al., 1995; Gombosi et al., 2009]. Our model of crustal duplex formation and forward propagation of the orogenic wedge [Torres Carbonell and Dimieri, 2013] suggests that this rapid uplift generated a strain-rate increase in the thrust front.

We infer that the same process of pore pressure buildup accompanying foreland sedimentation and strain-rate increase, ultimately led to the propagation of the basal detachment to shallower levels, namely the shaly horizons at the base of the Paleogene. From an economic viewpoint, it is also interesting to consider the potential maturation and generation of hydrocarbons in some Paleocene shales as a contribution to fluid pressure, such as has been proposed for the Lower Cretaceous shales [Zanella et al., 2014]. 
Thus, it is probable that much of the style change along and across the thrust-fold belt depends not only on causes such as lateral increase in orogenic strain, or the effect of buttressing against the Río Chico Arch, or on first-order processes such as coulomb wedge dynamics previously interpreted for the eastern thrust-fold belt [Torres Carbonell et al., 2011]. The variable involvement of Detachment $\mathrm{K}$ and Detachment $\mathrm{P}$ in the different crosssections, for example, could be dependent on changes in pore pressure buildup caused by the interaction of overburden, mean rock impermeability, and strain-rate.

\section{Conclusions}

We present four balanced cross-sections of the Fuegian thrust-fold belt based on the structural interpretation of an extensive dataset of seismic lines, integrated with surface geological data, allowing reconstruction of the structure from the thrust front to the internal thrust-fold belt. These cross-sections give first-order constraints on the structural style and minimum shortening of the thrust-fold belt, a major prospect in the exploratory frontier of the Austral-Magallanes basin. These constraints involve the distinction of three main structural packages in the thrust-fold belt: basement (including Jurassic strata), a Cretaceous package and a Paleogene package, which are separated by two major detachments.

The structural style markedly changes along the strike of the studied portion of the trust-fold belt. The eastern part has features analogous to those described in surface-based structural interpretations along the Atlantic coast of Tierra del Fuego: higher shortening in the Paleogene package (up to 43\%), buttressing against an important basement promontory, and a major role of the detachment at the base of the Paleogene package in accommodating shortening in the external thrust-fold belt. In the west of our study area, however, the style changes and the basement is more involved in the deformation, with the frontal basement 
thrust reaching the leading edge of the thrust-fold belt. Shortening is reduced $(\sim 16 \%$ in the Paleogene package), and the detachment at the base of the Paleogene is less important. The involvement of basement thrust-sheets in the thrust-fold belt evolution is evidenced for the first time from subsurface data, and this evidence supports previous interpretations of the role of basement duplexing in transferring orogenic shortening to the foreland. Accordingly, the basement duplex that exports deformation toward the foreland was active until late Oligocene or early Miocene times, as recorded by progressive unconformities in the thrust front, consistent at least with the published Paleogene uplift and exhumation of basement rocks in the central belt of the Fuegian Andes.

The temporal evolution of the thrust-fold belt during the early Paleogene was characterized by thrust imbrication in the internal thrust-fold belt, which was carried toward the foreland above a weak detachment at the base of the Cretaceous package, with a blocked termination line. Deposition of Eocene sediments with low mean permeability in front of this initial thrust wedge, as well as an increase in strain-rate associated to rapid uplift in the hinterland, caused pore pressure buildup ahead of the blockage due to combined overburden and tectonic compaction. This led to renewed propagation of the detachment. The same process of combined sedimentation and strain-rate increase, inducing pore pressure buildup in low permeability horizons, probably created the suitable detachment at the base of the Paleogene package. We infer that variations in pore pressure in the detachment horizons, dependent on the interactions among overburden, mean rock impermeability, and strain-rate, are important controls on the structural style changes along and across the thrust-fold belt.

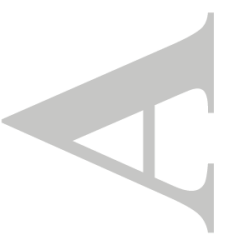




\section{Acknowledgments}

We acknowledge financial support from ANPCyT-FONCyT PICT 2012-2495 and ANPCyT-FONCyT PICT 2015-0419. The provision of an academic license from Midland Valley for the Move software (version 2015-2016.2) is greatly appreciated. The Secretaría de Energía e Hidrocarburos de la Provincia de Tierra del Fuego allowed access to some seismic lines. The authors would like to thank YPF S.A. for providing the seismic and well data, and allowing its publication. The data used is either published, or can be obtained from the first author. Reviews by J. Kley, D. Barbeau, and Associate Editor L. Schoenbohm were very helpful and greatly appreciated.

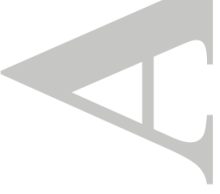

\section{References}

Agarwal, K., I. Singh, M. Sharma, S. Sharma, and G. Rajagopalan (2002), Extensional tectonic activity in the cratonward parts (peripheral bulge) of the Ganga Plain foreland basin, India, International Journal of Earth Sciences, 91(5), 897-905, doi:10.1007/s00531-002-0265-z.

Alvarez-Marrón, J., K. McClay, S. Harambour, L. Rojas, and J. Skarmeta (1993), Geometry and evolution of the frontal part of the Magallanes foreland thrust and fold belt (Vicuña Area), Tierra del Fuego, Southern Chile, AAPG Bulletin, 77, 1904-1921.

Atencio, M., F. Späth, and D. Rendon (2014), Caracterización de discontinuidades sísmicas: cálculo y procesos de atributos sobre amplitud, paper presented at IX Congreso de Exploración y Desarrollo de Hidrocarburos. Simposio de Geofísica, Instituto Argentino del Petróleo y del Gas, Mendoza. 
Betka, P., K. Klepeis, and S. Mosher (2015), Along-strike variation in crustal shortening and kinematic evolution of the base of a retroarc fold-and-thrust belt: Magallanes, Chile $53^{\circ} \mathrm{S}-54^{\circ} \mathrm{S}$, GSA Bulletin, doi:10.1130/b31130.1.

Barbeau, J., D.L., E. B. Olivero, N. L. Swanson-Hysell, K. M. Zahid, K. E. Murray, and G. E. Gehrels (2009), Detrital-zircon geochronology of the eastern Magallanes foreland basin: implications for Eocene kinematics of the northern Scotia Arc and Drake Passage, Earth and Planetary Science Letters, 284(3-4), 489-503.

Biddle, K., M. Uliana, R. Mitchum Jr., M. Fitzgerald, and R. Wright (1986), The stratigraphic and structural evolution of the central and eastern Magallanes Basin, southern South America, in Foreland Basins. IAS Special Publication, vol. 8, edited by P. A. Allen and P. Homewood, pp. 41-66, Blackwell.

Bradley, D. C., and W. S. F. Kidd (1991), Flexural extension of the upper continental crust in collisional foredeeps, GSA Bulletin, 103(11), 1416-1438, doi:10.1130/00167606(1991)103\&lt;1416:FEOTUC\&gt;2.3.CO;2.

Bruhn, R. L. (1979), Rock structures formed during back-arc basin deformation in the Andes of Tierra del Fuego, Geological Society of America Bulletin, 90(11), 998-1012.

Bry, M., N. White, S. Singh, R. England, and C. Trowell (2004), Anatomy and formation of oblique continental collision: South Falkland basin, Tectonics, 23(4), TC4011, doi:10.1029/2002tc001482.

Bulhões, É. M., and W. Nogueira de Amorim (2005), Princípio da SismoCamada Elementar e sua aplicação à Técnica Volume de Amplitudes (tecVA), paper presented at 9th International Congress of the Brazilian Geophysical Society, Sociedade Brasileira de Geofísica, Salvador. 
Calderón, M., A. Fildani, F. Hervé, C. M. Fanning, A. Weislogel, and U. Cordani (2007), Late Jurassic bimodal magmatism in the northern sea-floor remnant of the Rocas Verdes basin, southern Patagonian Andes, Journal of the Geological Society, London, 164, 1011-1022, doi:doi:10.1144/0016-76492006-102.

Cello, G., and A. Nur (1988), Emplacement of foreland thrust systems, Tectonics, 7(2), 261271, doi:10.1029/TC007i002p00261.

Cunningham, W. D. (1995), Orogenesis at the southern tip of the Americas: the structural evolution of the Cordillera Darwin metamorphic complex, southernmost Chile, Tectonophysics, 244(4), 197-229.

Dalziel, I. W. D. (1986), Collision and Cordilleran orogenesis: an Andean perspective, Geological Society, London, Special Publications, 19, 389-404, doi:10.1144/gsl.sp.1986.019.01.22.

Dalziel, I. W. D., L. A. Lawver, I. O. Norton, and L. M. Gahagan (2013), The Scotia Arc: Genesis, Evolution, Global Significance, Annual Review of Earth and Planetary Sciences, 41(1), 767-793, doi:10.1146/annurev-earth-050212-124155.

Dimieri, L. V., and M. M. Turienzo (2012), Comment on: "Fault inversion vs. new thrust generation: A case study in the Malargüe fold-and-thrust belt, Andes of Argentina" by J. F. Mescua, and L. B. Giambiagi, Journal of Structural Geology 35 (2012) 51-63, Journal of Structural Geology, 42, 279-282, doi:10.1016/j.jsg.2012.05.014.

Fildani, A., and A. M. Hessler (2005), Stratigraphic record across a retroarc basin inversion: Rocas Verdes-Magallanes Basin, Patagonian Andes, Chile, GSA Bulletin, 117(11/12), 1596-1614, doi:doi: 10.1130/B25708.1. 
Flores, M. A., N. Malumián, V. Masiuk, and J. C. Riggi (1973), Estratigrafía cretácica del subsuelo de Tierra del Fuego, Revista de la Asociación Geológica Argentina, 28, $407-437$.

Ghiglione, M. C., J. Quinteros, D. Yagupsky, P. Bonillo-Martínez, J. Hlebszevtich, V. A. Ramos, G. Vergani, D. Figueroa, S. Quesada, and T. Zapata (2010), Structure and tectonic history of the foreland basins of southernmost South America, Journal of South American Earth Sciences, 29(2), 262-277, doi:10.1016/j.jsames.2009.07.006.

Ghiglione, M. C., A. T. Navarrete-Rodríguez, M. González-Guillot, and G. Bujalesky (2012), The opening of the Magellan Strait and its geodynamic implications, Terra Nova, doi:10.1111/j.1365-3121.2012.01090.x.

Gombosi, D. J., D. L. Barbeau Jr, and J. I. Garver (2009), New thermochronometric constraints on the rapid Palaeogene exhumation of the Cordillera Darwin complex and related thrust sheets in the Fuegian Andes, Terra Nova, 21, 507-515.

Klepeis, K. A., P. Betka, G. Clarke, M. Fanning, F. Hervé, L. Rojas, C. Mpodozis, and S. Thomson (2010), Continental underthrusting and obduction during the Cretaceous closure of the Rocas Verdes rift basin, Cordillera Darwin, Patagonian Andes, Tectonics, 29(3), TC3014, doi:10.1029/2009tc002610.

Kley, J., C. R. Monaldi, and J. A. Salfity (1999), Along-strike segmentation of the Andean foreland: causes and consequences, Tectonophysics, 301(1-2), 75-94, doi:10.1016/s0040-1951(98)90223-2.

Kohn, M. J., F. S. Spear, and I. W. D. Dalziel (1993), Metamorphic P-T Paths from Cordillera Darwin, a Core Complex in Tierra del Fuego, Chile, Journal of Petrology, 34(3), 519-542, doi:10.1093/petrology/34.3.519. 
Kohn, M. J., F. S. Spear, T. M. Harrison, and I. W. D. Dalziel (1995), 40Ar/39Ar geochronology and P-T-t paths from the Cordillera Darwin metamorphic complex, Tierra del Fuego, Chile, Journal of Metamorphic Geology, 13(2), 251-270.

Kraemer, P. E. (2003), Orogenic shortening and the origin of the Patagonian orocline $\left(56^{\circ}\right.$ S.Lat), Journal of South American Earth Sciences, 15(7), 731-748.

Lacombe, O., and N. Bellahsen (2016), Thick-skinned tectonics and basement-involved foldthrust belts: insights from selected Cenozoic orogens, Geological Magazine, 153(5-6), $763-810$.

Londoño, J., and J. M. Lorenzo (2004), Geodynamics of continental plate collision during late Tertiary foreland basin evolution in the Timor Sea: constraints from foreland sequences, elastic flexure and normal faulting, Tectonophysics, 392(1-4), 37-54, doi:http://dx.doi.org/10.1016/j.tecto.2004.04.007.

Malumián, N., and E. B. Olivero (2006), El Grupo Cabo Domingo, Tierra del Fuego: bioestratigrafía, paleoambientes y acontecimientos del Eoceno-Mioceno marino, Revista de la Asociación Geológica Argentina, 61, 139-160.

Marshak, S. (2004), Salients, recesses, arcs, oroclines, and syntaxes-A review of ideas concerning the formation of map-view curves in fold-thrust belts, in Thrust tectonics and hydrocarbon systems: AAPG Memoir, vol. 82, edited by K. R. McClay, pp. 131-156, American Association of Petroleum Geologists.

Martinioni, D. R., E. B. Olivero, and S. Palamarczuk (1999), Estratigrafía y discordancias del Cretácico Superior-Paleoceno en la región central de Tierra del Fuego, Simposio del Paleogeno de América del Sur (Buenos Aires, 1996), Actas, Anales 33, 7-16. 
Martinioni, D. R., E. B. Olivero, F. A. Medina, and S. C. Palamarczuk (2013), Cretaceous stratigraphy of Sierra de Beauvoir, Fuegian Andes (Argentina), Revista de la Asociación Geológica Argentina, 70(1), 70-95.

Masiuk, V., J. C. Riggi, and J. L. Bianchi (1990), Análisis geológico del Terciario del subsuelo de Tierra del Fuego, Boletín de Informaciones Petroleras, 21, 70-89.

Mescua, J. F., and L. B. Giambiagi (2012), Fault inversion vs. new thrust generation: A case study in the Malargüe fold-and-thrust belt, Andes of Argentina, Journal of Structural Geology, 35, 51-63, doi:10.1016/j.jsg.2011.11.011.

Mourgues, R., and P. R. Cobbold (2006), Thrust wedges and fluid overpressures: Sandbox models involving pore fluids, Journal of Geophysical Research: Solid Earth, 111(B5), B05404, doi:10.1029/2004jb003441.

Nelson, E. P. (1982), Post-tectonic uplift of the Cordillera Darwin orogenic core complex: evidence from fission track geochronology and closing temperature-time relationships, Journal of the Geological Society, 139(6), 755-761.

Nelson, E. P., I. W. D. Dalziel, and A. G. Milnes (1980), Structural geology of the Cordillera Darwin - Collisional-style orogenesis in the southernmost Chilean Andes, Eclogae Geologicae Helvetiae, 73, 727-751.

Olivero, E. B., and N. Malumián (2008), Mesozoic-Cenozoic stratigraphy of the Fuegian Andes, Argentina, Geologica Acta, 6(1), 5-18.

Olivero, E. B., N. Malumián, and S. Palamarczuk (2003), Estratigrafía del Cretácico Superior-Paleoceno del área de Bahía Thetis, Andes fueguinos, Argentina: acontecimientos tectónicos y paleobiológicos, Revista Geológica de Chile, 30, $245-263$. 
Panza, J., L. Sacomani, and J. Cobos (2002), Mapa geológico de la provincia de Santa Cruz, scale 1:750,000, Servicio Geológico y Minero de Argentina, Buenos Aires.

Platt, N. H., and P. R. Philip (1995), Structure of the southern Falkland Islands continental shelf: initial results from new seismic data, Marine and petroleum geology, 12(7), 759-771, doi:http://dx.doi.org/10.1016/0264-8172(95)93600-9.

Poblete, F., P. Roperch, C. Arriagada, G. Ruffet, C. Ramírez de Arellano, F. Hervé, and M. Poujol (2016), Late Cretaceous-early Eocene counterclockwise rotation of the Fueguian Andes and evolution of the Patagonia-Antarctic Peninsula system, Tectonophysics, 668-669, 15-34, doi:http://dx.doi.org/10.1016/j.tecto.2015.11.025.

Ramsay, J. G. (1967), Folding and fracturing of rocks, McGraw-Hill, New York.

Ramsay, J. G., R. W. H. Butler, and M. P. Coward (1988), General Discussion, Philosophical Transactions of the Royal Society of London A: Mathematical, Physical and Engineering Sciences, 326, 321-325, doi:10.1098/rsta.1988.0090.

Rojas, L., and C. Mpodozis (2006), Geología estructural de la faja plegada y corrida de Tierra del Fuego, Andes Patagónicos Chilenos, paper presented at XI Congreso Geológico Chileno, Antofagasta.

SERNAGEOMIN (2003), Mapa Geológico de Chile, scale 1:1,000,000, Servicio Nacional de Geología y Minería, Santiago.

Suppe, J. (1983), Geometry and kinematics of fault-bend folding, American Journal of Science, 283(7), 684-721.

Suppe, J., and D. A. Medwedeff (1990), Geometry and kinematics of fault-propagation folding, Eclogae Geologicae Helvetiae, 83(3), 409-454. 
Tanner, P. W. G., and D. I. M. Macdonald (1982), Models for the deposition and simple shear deformation of a turbidite sequence in the South Georgia portion of the southern Andes back-arc basin, Journal of the Geological Society, 139(6), 739-754.

Torres Carbonell, P. J., and L. V. Dimieri (2013), Cenozoic contractional tectonics in the Fuegian Andes, southernmost South America: a model for the transference of orogenic shortening to the foreland, Geologica Acta, 11(3), 359-370, doi:10.1344/105.000001874.

Torres Carbonell, P. J., and E. B. Olivero (2012), Sand dispersal in the southeastern Austral Basin, Tierra del Fuego, Argentina: Outcrop insights from Eocene channeled turbidite systems, Journal of South American Earth Sciences, 33(1), 80-101, doi:10.1016/j.jsames.2011.08.002.

Torres Carbonell, P. J., L. V. Dimieri, and E. B. Olivero (2011), Progressive deformation of a Coulomb thrust wedge: the eastern Fuegian Andes Thrust-Fold Belt, Geological Society, London, Special Publication, 349, 123-147, doi:10.1144/SP349.7.

Torres Carbonell, P. J., L. V. Dimieri, and E. B. Olivero (2013a), Evaluation of strain and structural style variations along the strike of the Fuegian thrust-fold belt front, Argentina, Andean Geology, 40(3), 438-457, doi:10.5027/andgeoV40n3-a03.

Torres Carbonell, P. J., L. V. Dimieri, and D. R. Martinioni (2013b), Early foreland deformation of the Fuegian Andes (Argentina): Constraints from the strain analysis of Upper Cretaceous-Danian sedimentary rocks, Journal of Structural Geology, 48, 14-32, doi:http://dx.doi.org/10.1016/j.jsg.2012.12.010.

Torres Carbonell, P. J., L. V. Dimieri, E. B. Olivero, F. Bohoyo, and J. Galindo-Zaldívar (2014), Structure and tectonic evolution of the Fuegian Andes (southernmost South 
America) in the framework of the Scotia Arc development, Global and Planetary Change, 123, Part B, 174-188, doi:http://dx.doi.org/10.1016/j.gloplacha.2014.07.019.

von Hartmann, H., D. C. Tanner, and S. Schumacher (2016), Initiation and development of normal faults within the German alpine foreland basin: The inconspicuous role of basement structures, Tectonics, 35(6), 1560-1574, doi:10.1002/2016tc004176.

Walder, J., and A. Nur (1984), Porosity reduction and crustal pore pressure development, Journal of Geophysical Research: Solid Earth, 89(B13), 11539-11548, doi:10.1029/JB089iB13p11539.

Zanella, A., P. R. Cobbold, and L. Rojas (2014), Beef veins and thrust detachments in Early Cretaceous source rocks, foothills of Magallanes-Austral Basin, southern Chile and Argentina: Structural evidence for fluid overpressure during hydrocarbon maturation, Marine and Petroleum Geology, 55, 250-261, doi:http://dx.doi.org/10.1016/j.marpetgeo.2013.10.006.

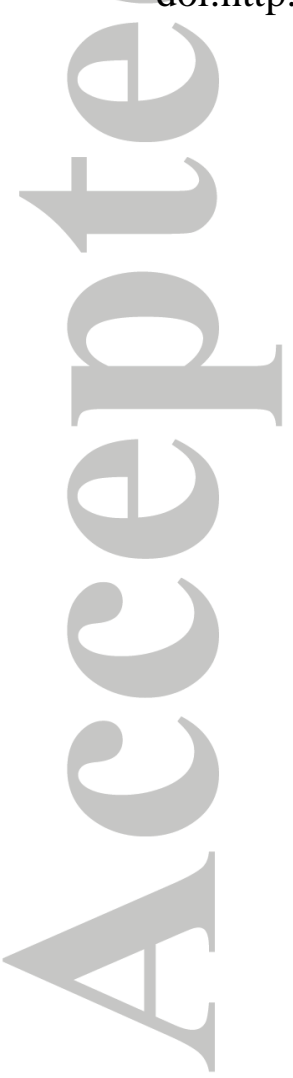


Table 1. Synthesis of shortening estimates in the Fuegian Andes ${ }^{a}$

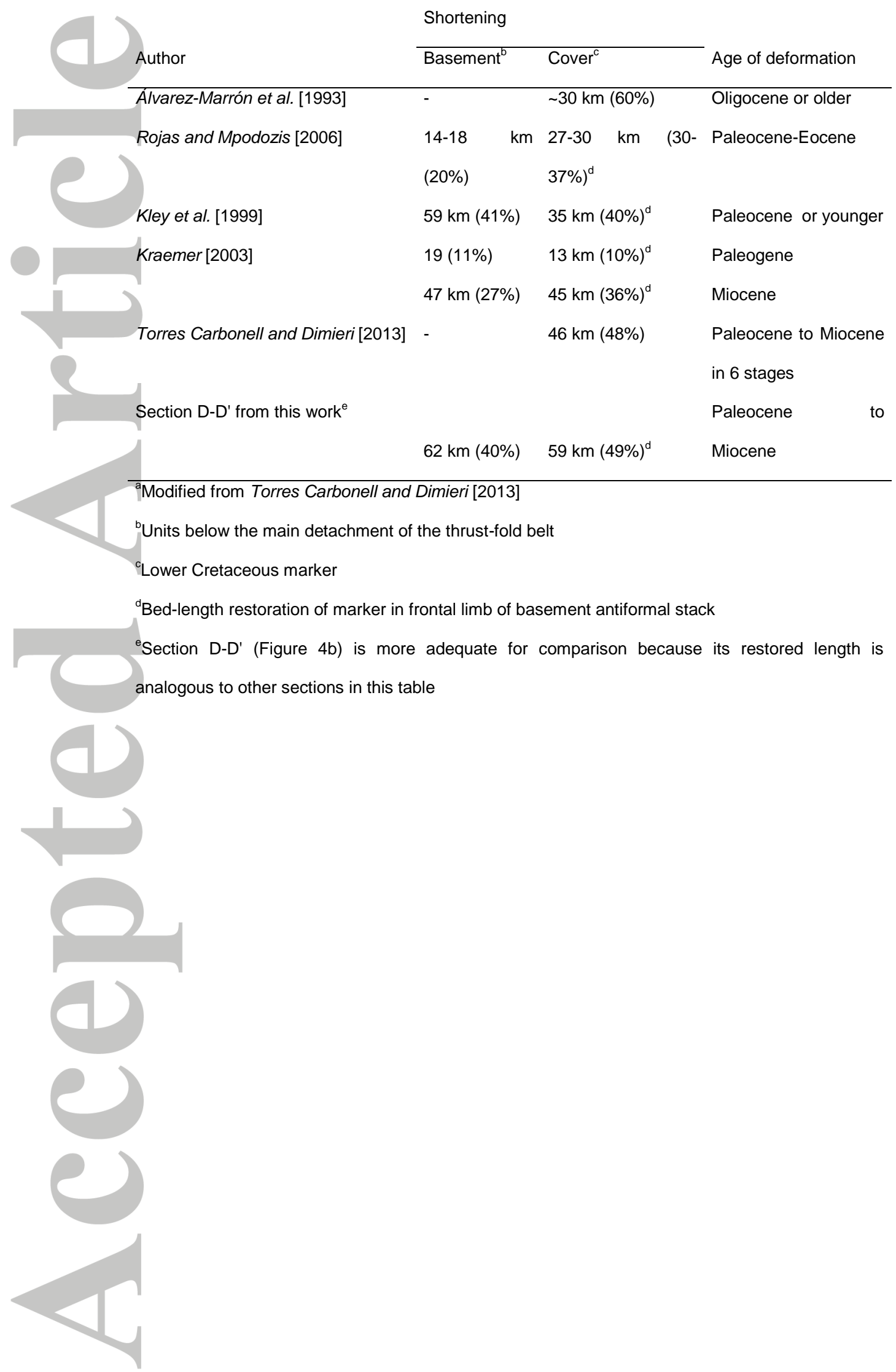




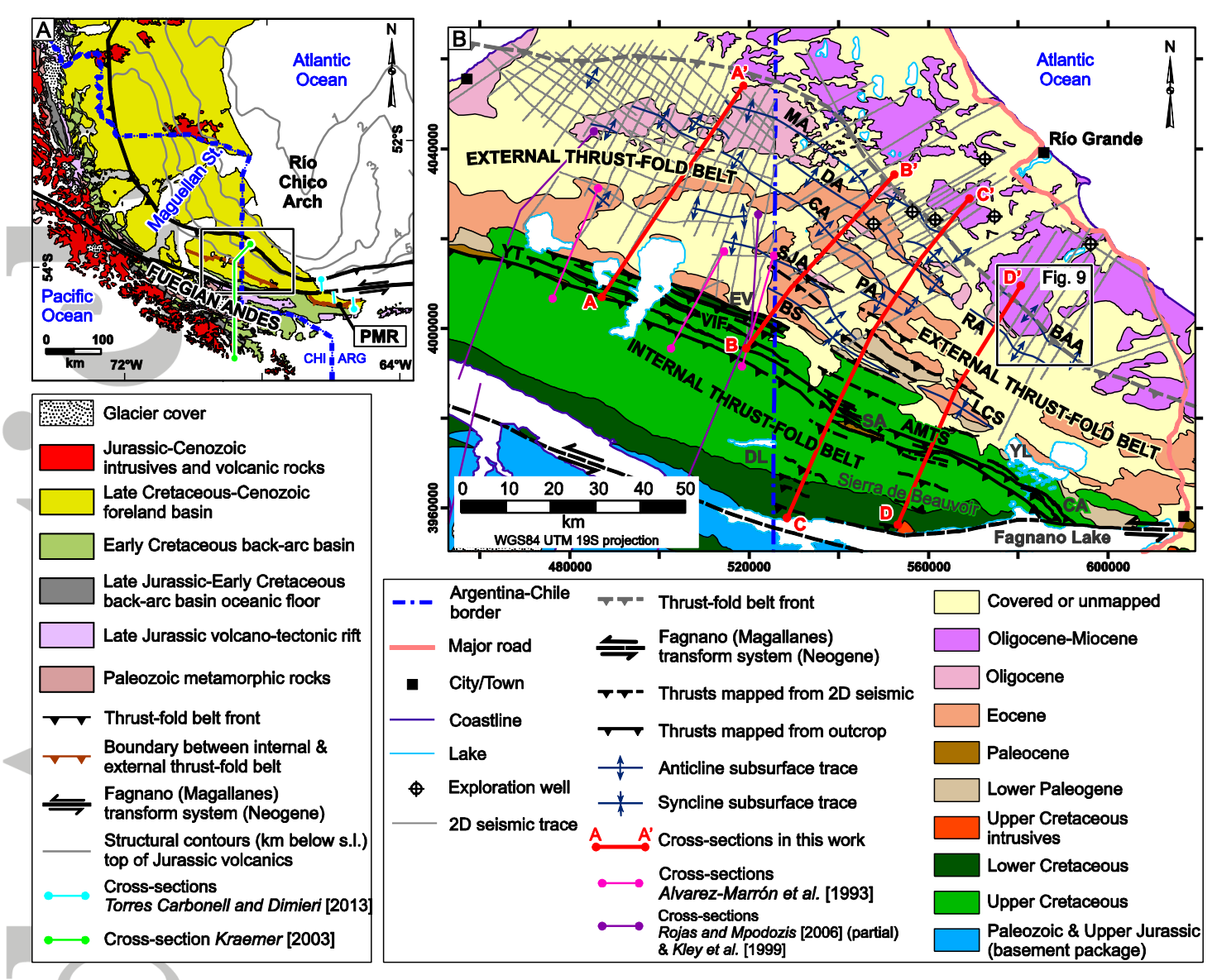

Figure 1. Regional (a) and study area (b) geological maps. Compiled and modified from Panza et al. [2002], SERNAGEOMIN [2003], Olivero and Malumián [2008], Klepeis et al. [2010], Torres Carbonell et al. [2013a, b], Zanella et al. [2014]. PMR: Península Mitre recess, YT: Yartou thrust, VIF: Vicuña imbricate fan, AMTS: Apen-Malvinera thrust system, LCS: Los Cerros syncline, BS: Ballena syncline, SJA: San Justo anticline, PA: Pilarica anticline, CA: Constancia anticline, DA: Despedida anticline, RA: Ruby anticline, BAA: Buenos Aires anticline, MA: Moneta anticline, DL: Deseado Lake, CA: Cerro Atukoyak, SA: Sierra de Apen, YL: Yehuin Lake, EV: Estancia Vicuña. 


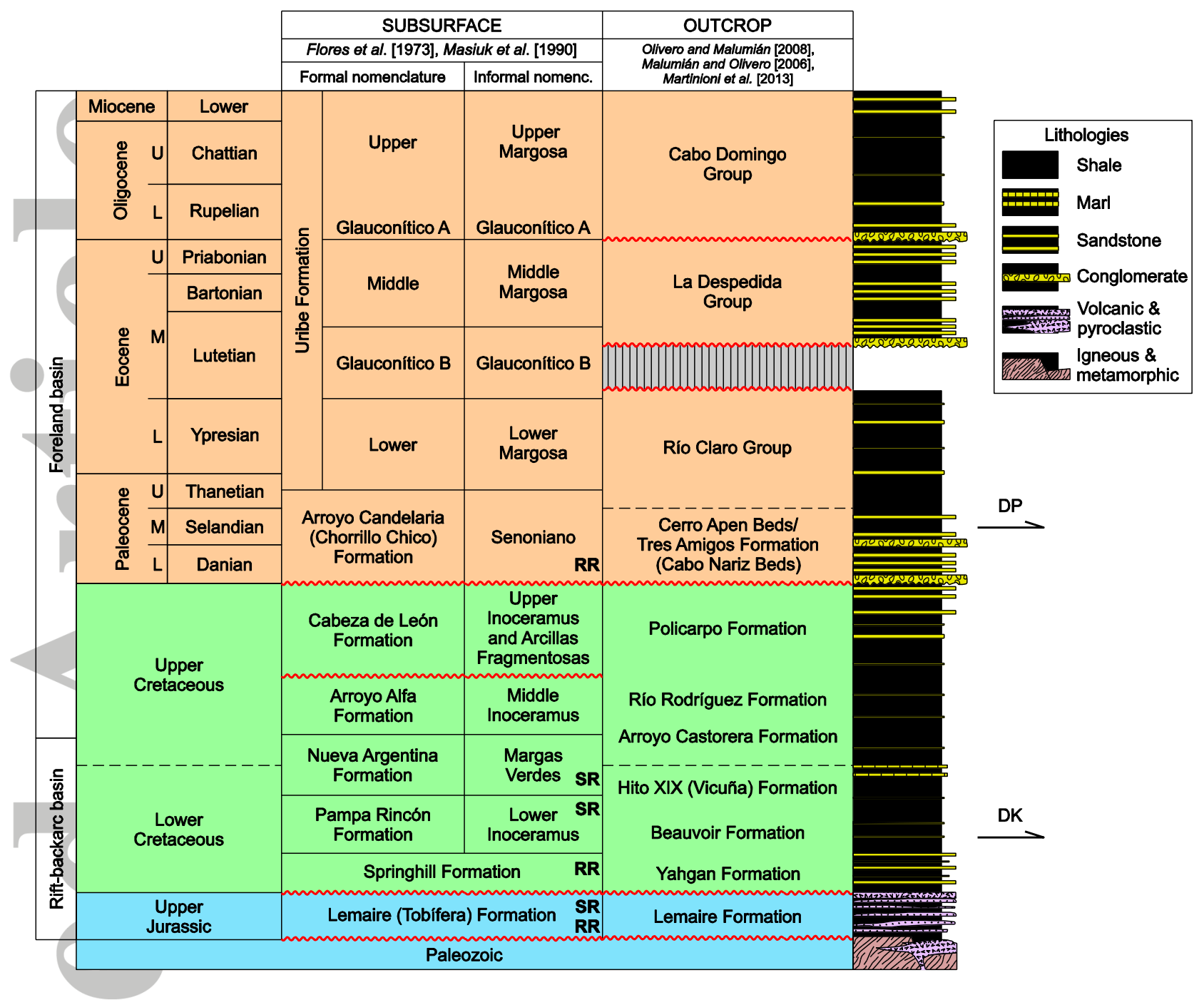

Figure 2. Stratigraphic framework of the thrust-fold belt in Argentine Tierra del Fuego, based on the cited subsurface and outcrop studies. Some prominent names used in Chile are within brackets. The approximate location of the main detachments (DK and DP) are shown, and fill colors correspond to the basement package (cyan), Cretaceous package (green) and Paleogene package (orange). SR and RR are the source and reservoir rocks, respectively, of the main operational hydrocarbon systems in Tierra del Fuego. Chronostratigraphic boundaries for the Cenozoic units are based on recent geochronology[cf. Malumián and Olivero, 2006; Olivero and Malumián, 2008]. U: Upper; M: Middle; L: Lower. An idealized lithologic column is shown, although lateral facies variations exist along the thrust-fold belt. 


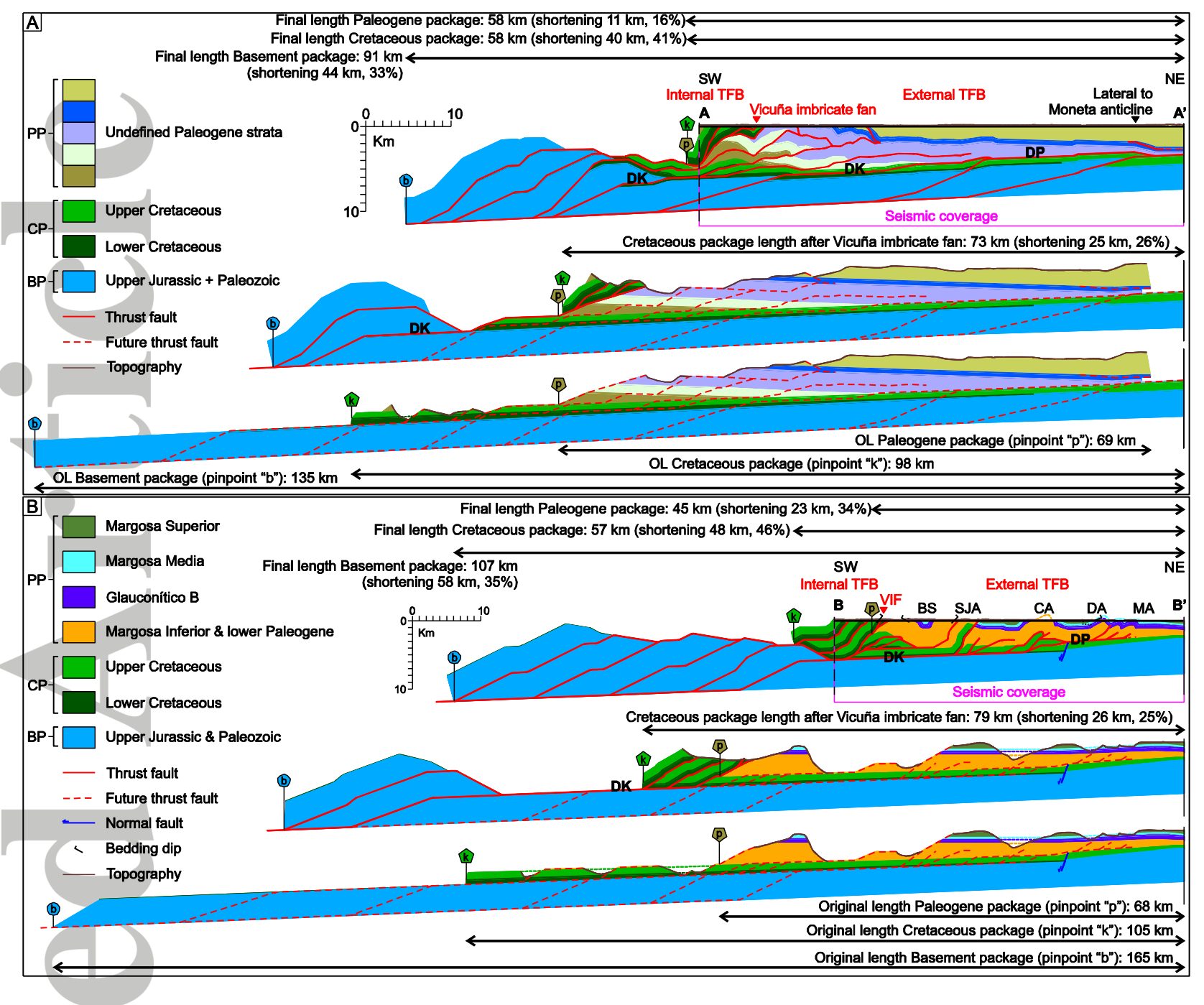

Figure 3. Balanced cross-sections A-A' (a) and B-B' (b) (locations shown in Figure 1b).

Basement structures are idealized to give idea of the duplex necessary to produce the shortening in the thrust-fold belt (TFB). OL: Original length, VIF: Vicuña imbricate fan, BS: Ballena syncline, SJA: San Justo anticline, CA: Constancia anticline, DA: Despedida anticline, MA: Moneta anticline, PP: Paleogene package, CP: Cretaceous package, BP: basement package, DP: Detachment P, DK: Detachment K. 


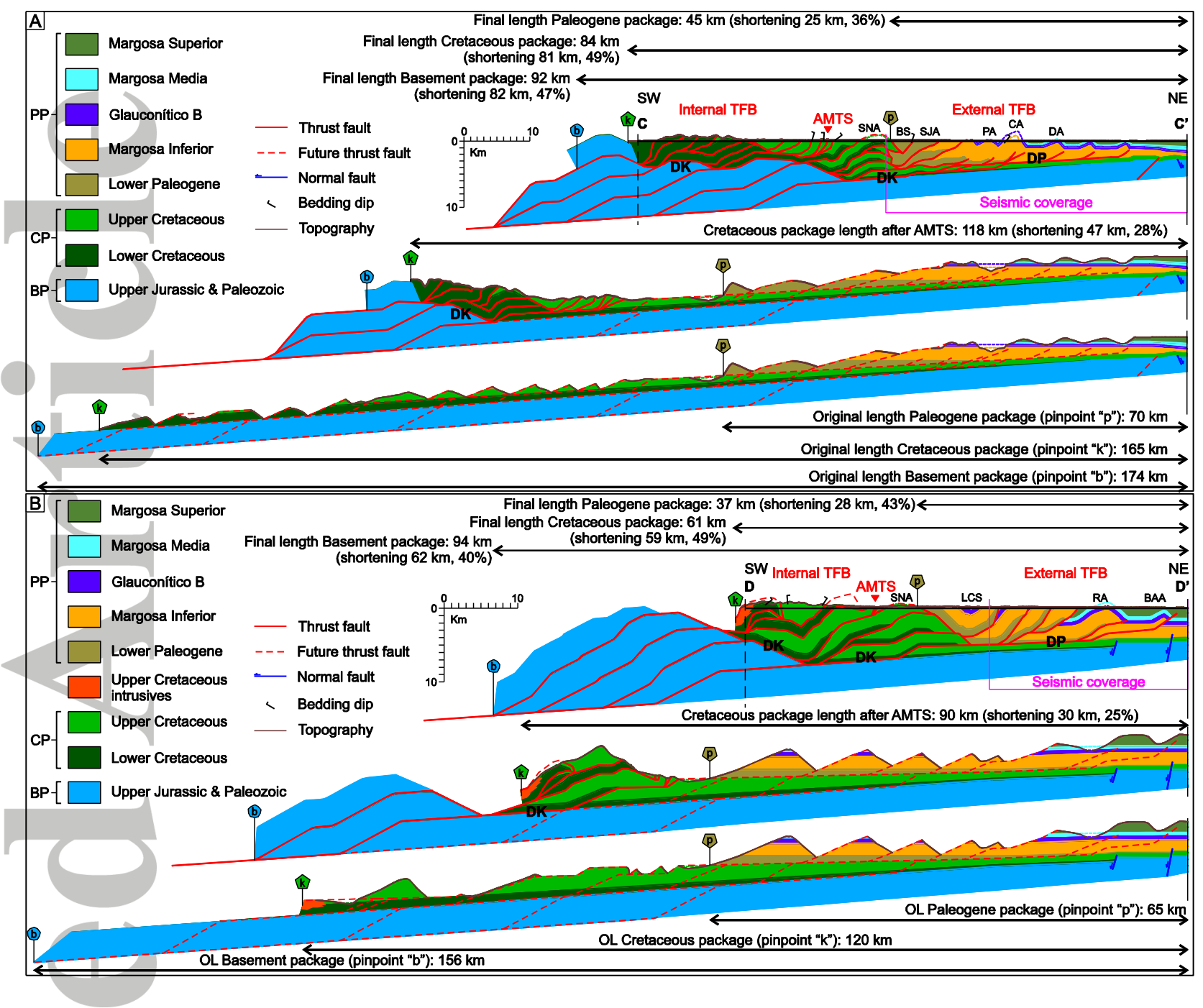

Figure 4. Balanced cross-sections C-C' (a) and D-D' (b) (locations shown in Figure 1b). Basement structures are idealized to give idea of the duplex necessary to produce the shortening in the thrust-fold belt (TFB). OL: Original length, AMTS: Apen-Malvinera thrust system, SNA: Sierra Nevada antiform, BS: Ballena syncline, SJA: San Justo anticline, PA: Pilarica anticline, CA: Constancia anticline, DA: Despedida anticline, LCS: Los Cerros syncline, RA: Ruby anticline, BAA: Buenos Aires anticline, PP: Paleogene package, CP: Cretaceous package, BP: basement package, DP: Detachment P, DK: Detachment K. 


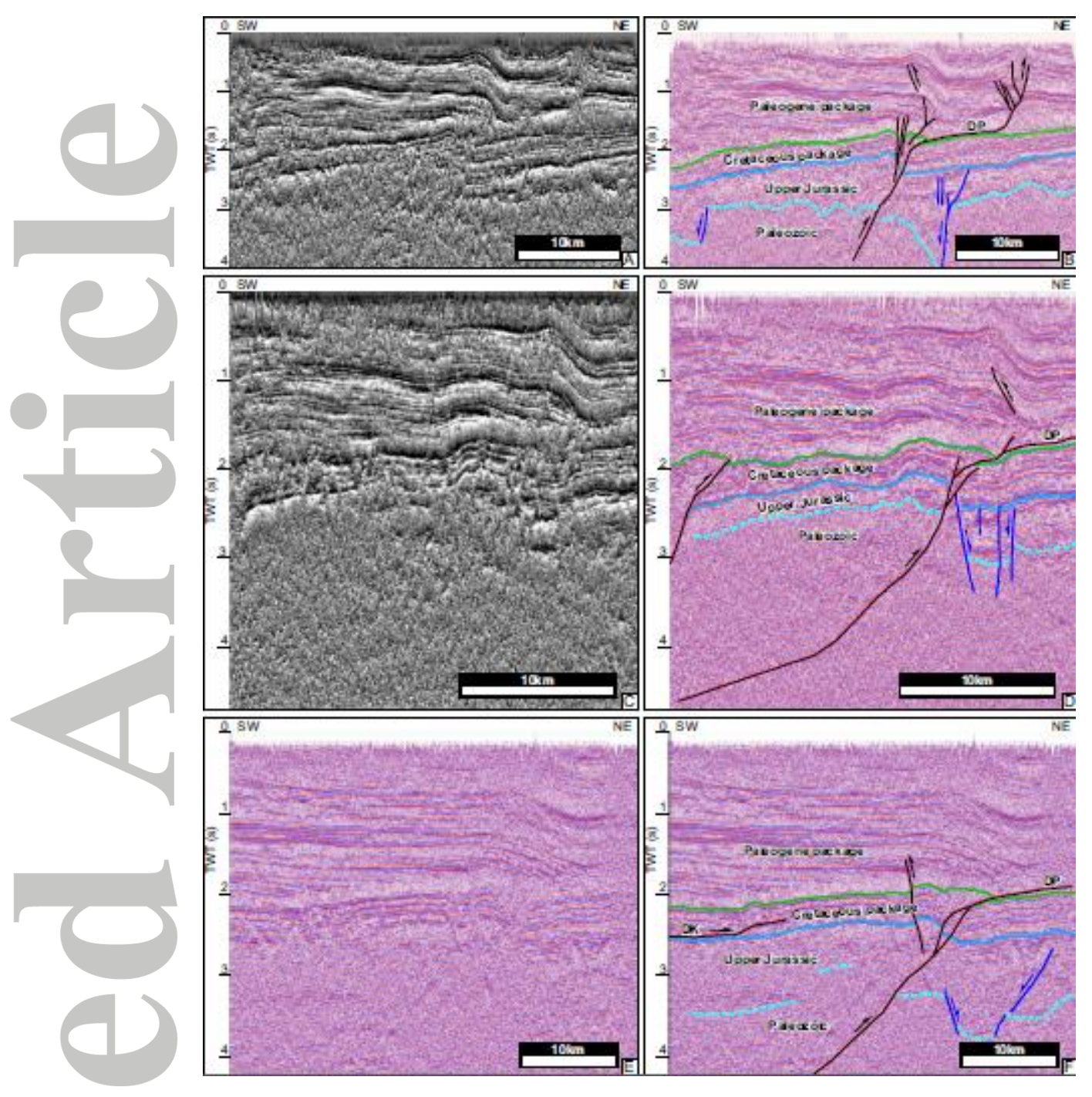

Figure 5. Examples of basement thrust-sheets uplifted at the thrust-fold belt front, all 2D seismic sections located within $10 \mathrm{~km}$ of section A-A' (Figure 3a). (a) and (c) are SimilTecVA processed lines corresponding to (b) and (d) interpreted lines, respectively. (e) uninterpreted line shown in (f). Red lines are thrust faults, blue lines are normal faults. Detachments DK and DP are shown, note that the Upper Jurassic and Paleozoic both form the basement package, as explained in the text. 


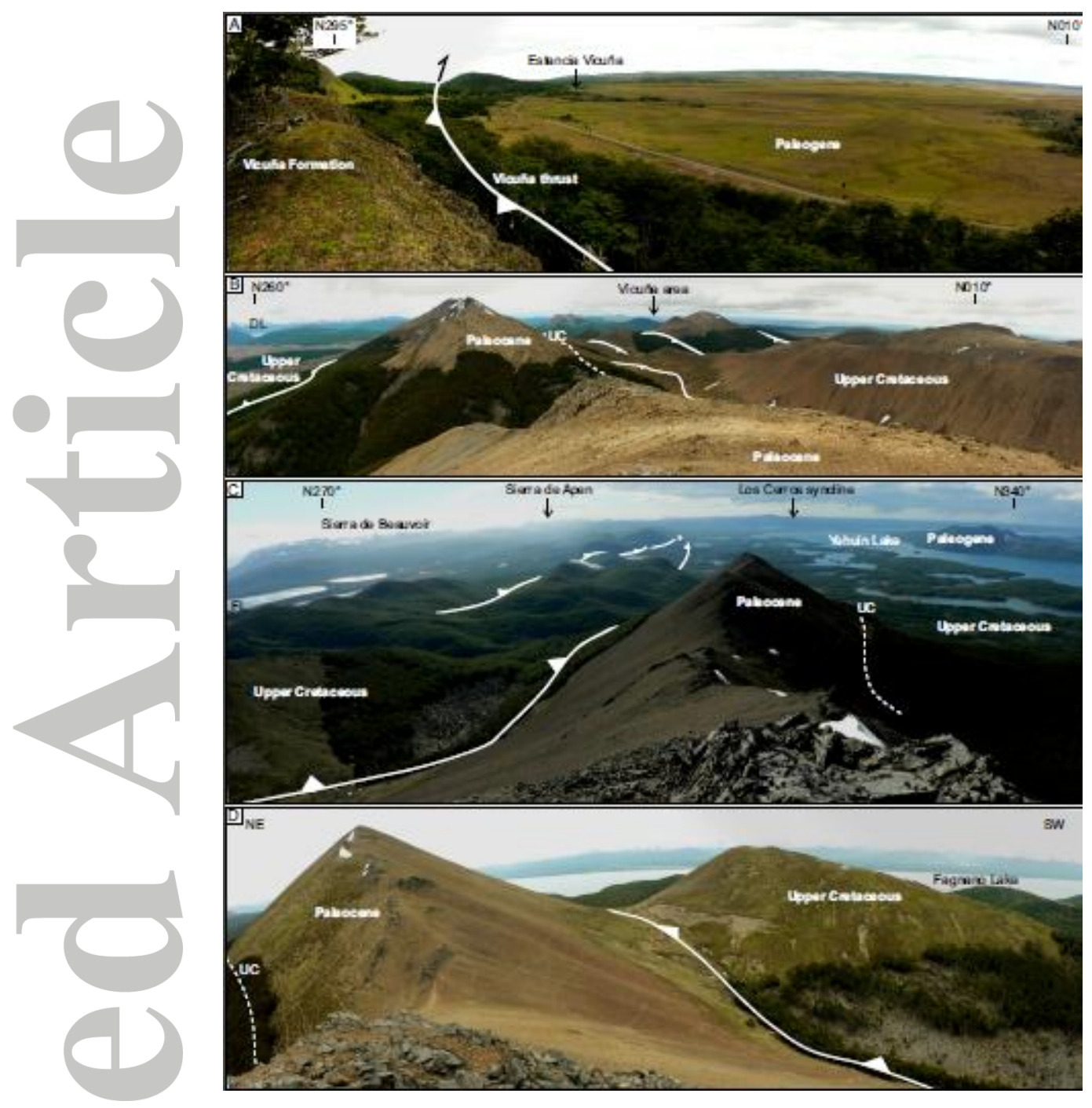

Figure 6. Outcrop examples of the boundary between the internal and external thrust-fold belt. (a) Vicuña thrust at the leading edge of the Vicuña imbricate fan. Note the sharp topographic break between the uplifted Lower Cretaceous rocks (Vicuña Formation) and the lowlands covering Paleogene successions. (b) AMTS at Sierra de Apen (Figure 1b), the Deseado Lake (DL) and Vicuña area are seen at the back. UC: unconformity between the Paleocene Cerro Apen Beds and the Upper Cretaceous Policarpo Formation (Figure 2). (c-d) AMTS at the Cerro Atukoyak (Figure 1b), viewing to the NW (in c) and to the SE (in d). FL: Fagnano Lake. 


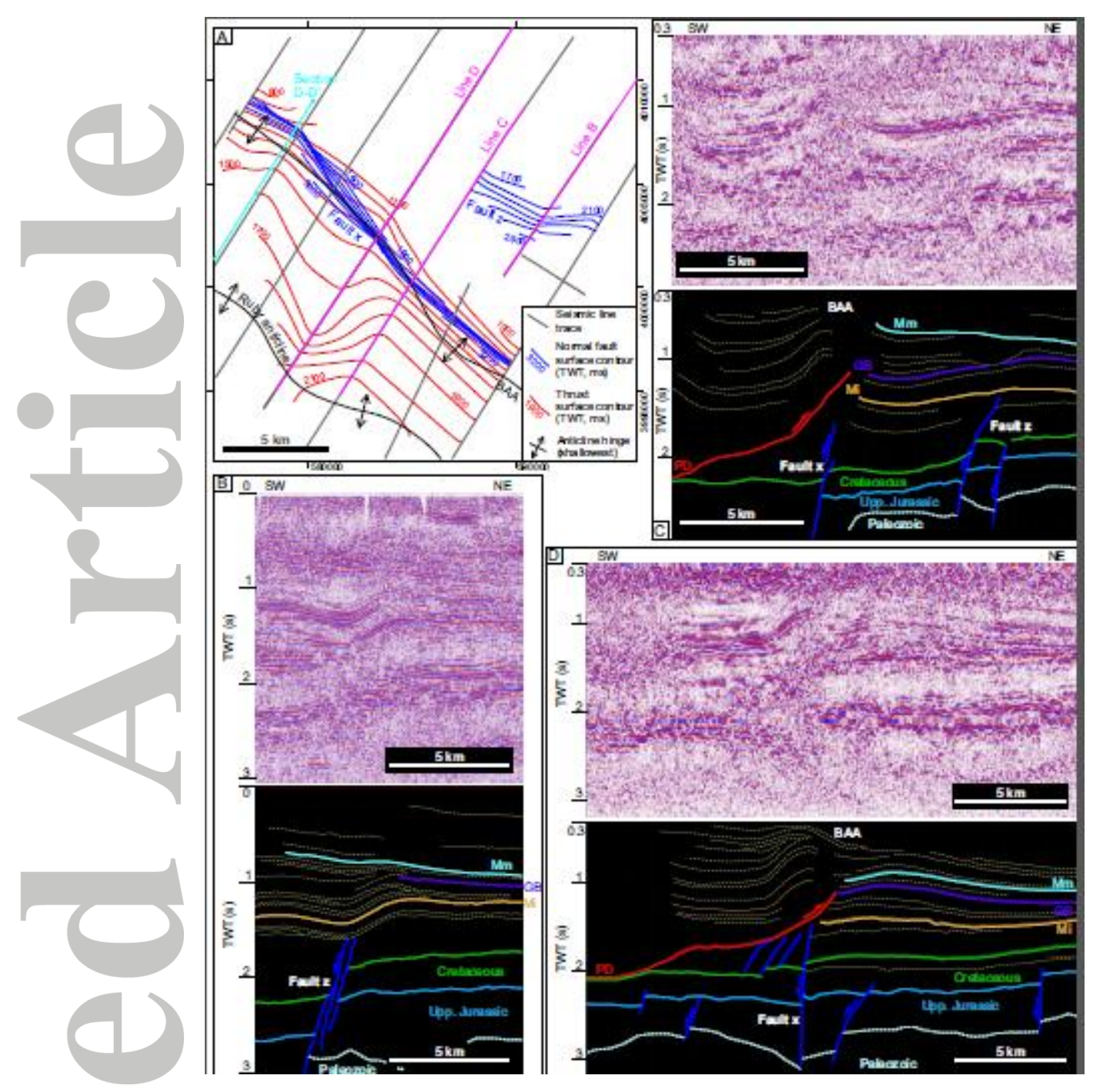

Figure 7. Detail of normal faults in the footwall of the thrust-fold belt and their influence on the location of ramps in the deformation front. (a) Structural map with main features of the selected area (located in Figure 1b). BAA: Buenos Aires anticline. The portions of 2D seismic sections shown in b-d are indicated. (b) Detail of growth strata linked to slip on fault z. Mm: top of Middle Margosa, GB: top of Glauconítico B, Mi: top of Lower Margosa. (c-d) Detail of the frontal structure of the thrust-fold belt (BAA), note that the frontal ramp branching from the PD detachment, and the related anticline, form above a step in the footwall owing to displacement on fault $\mathrm{x}$. Also note that the BAA is younger than fault $\mathrm{x}$, as revealed by the growth strata in the anticline, above the Mm marker, compared with the older growth strata related to the normal fault. 

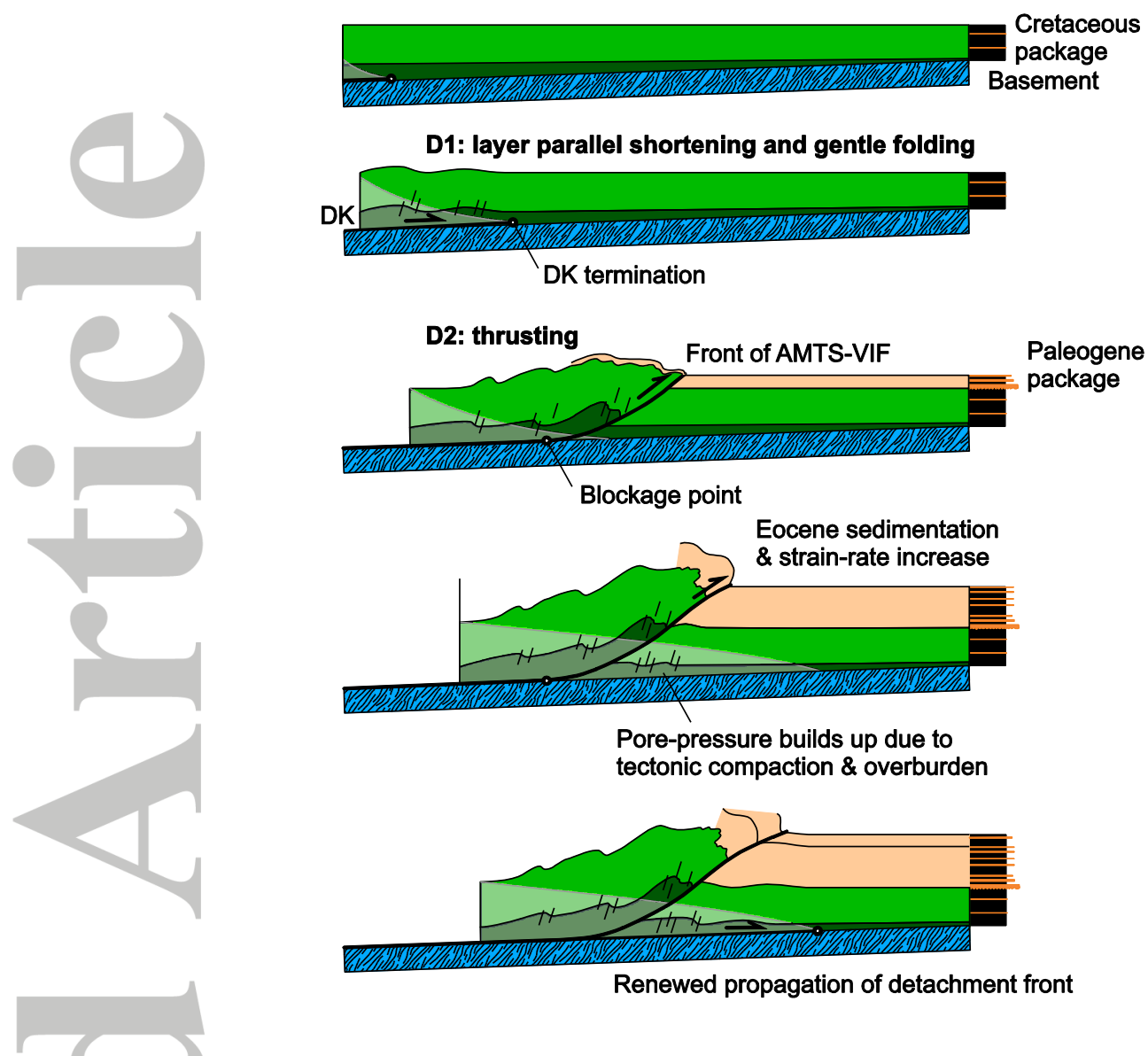

Figure 8. Idealized model of propagation of the thrust wedge above Detachment K (DK), controlled by the suitability of the latter, which is a function of high pore pressure (greyshaded area) depending on strain-rate, overburden, and the presence of impermeable layers (shale). A similar further evolution would create Detachment P. The columns to the right show idealized lithologies based on Figure 2. AMTS: Apen-Malvinera thrust system, VIF: Vicuña imbricate fan. Based on Cello and Nur [1988]. 